\title{
Current concepts in the metabolic responses to injury, infection and starvation
}

\author{
By J. R. RichaRDs, Department of Surgery, Royal Infirmary, Glasgow
}

The disruption of homoeostatic regulatory mechanisms by injury is well recognized. Survival depends upon a coordinated response by cardiovascular, renal, haematological, respiratory, neural and endocrine systems designed to provide continuing oxygen and nutrients to the cells of vital organs (Moore, 1977). This review is concerned with the biochemical and endocrine adaptation which occurs during the recovery period after injury to provide, in addition to the foregoing, materials for cellular and wound repair, materials for synthesis of immune and other proteins, and the necessary precursors for the long-term supply of metabolic energy. Starvation and infection, and their influence on the postinjury state are also considered.

\section{Early injury studies}

Current concepts of the response to injury as characterized by body-weight loss, negative nitrogen balance, increased resting metabolic rate, hormonal derangements, and fluid and electrolyte changes, originated with studies of $\mathbf{N}$ metabolism after surgery and haemorrhage, at the beginning of the twentieth century (Hawk \& Gies, 1904; Haskins, 1907). The inadequacy of medical treatment offered to the mass battle casualties of World War I provided the stimulus for further research (Duval \& Grigaut, 1918; Mestrezat, 1918; Wertheimer et al. 1919). But it was not until the 1930s that Cuthbertson in Scotland first described in detail the increased losses of urinary N, potassium, sulphur and phosphorus after injury in man which linked these biochemical changes with increased breakdown of body protein (Cuthbertson, 1930, 1931, 1932, 1934, 1936). Subsequent studies by others supported these initial observations (Howard et al. 1944; Moore \& Ball, 1952; Kreiger et al. 1954; Frawley et al. 1955). In general the timing and extent of $\mathrm{N}$ excretion after injury was related to the severity (Cuthbertson, 1942) and type of injury sustained (Davies et al. 1959), up to $7 \%$ of the total body $\mathrm{N}$ being lost over the first ro d after injury even in subjects with a normal food intake (Cuthbertson, 1932; Cairnie et al. 1957; Ministry of Health, 1964; Cuthbertson, 1972). Cuthbertson postulated that this catabolism of body protein might be part of a primitive survival reflex to supply body food requirements from endogenous resources at a time when injury prevented the search for an adequate food supply.

After severe infections such as typhoid fever (Shaffer, 1908; Shaffer \& Coleman, 1909) and other infections (Grossman et al. 1945; Howard et al. 1946; Peters, 1948), increased losses of body $\mathrm{N}$ were found which were related to the wasting of 
body tissues and, as in injury, were proportional to the losses of other intracellular elements such as $\mathrm{Na}, \mathrm{P}$ and $\mathrm{S}$.

\section{Changes in energy expenditure after injury}

Cuthbertson's belief that protein was the main body tissue catabolized as a fuel after trauma was reinforced by his finding that patients with bone fractures had an increased metabolic rate (Cuthbertson, 1932, 1970) which corresponded with the period of post-injury increased loss of urinary $N$ (Cuthbertson, 1931, 1936). From this, and subsequent rat studies, Cuthbertson and his co-workers (Cuthbertson et al. 1939; Cairnie et al. 1957), concluded that the post-injury increase in resting metabolism was due to "the heat resulting from the deamination of protein, and from the use of the non-nitrogenous residue as a source of energy'.

\section{Factors modifying the response to injury}

Many factors were investigated in search of the cause of these injury responses (Table 1). Particular emphasis was placed on the importance of diet, its composition and quantity, in the prevention of post-injury weight loss. Injured or septic subjects required higher $\mathrm{N}$ intakes than the uninjured or the uninfected to achieve $\mathrm{N}$ balance (Kinney, 1975, 1976). Diets offered to the injured, therefore, often lacked sufficient protein, or energy, or both, to achieve $\mathrm{N}$ equilibrium. This factor, perhaps more than any other, explained the post-injury negative $\mathrm{N}$ balance so often seen in patients (Moore \& Brennan, 1975). Though in certain severe injuries such as extensive full thickness burns (Soroff $e$ t al. 196r; Wilmore et al. 1971), or post-operative peritonitis (Kinney, 1976), marked weight loss and very large increases in urinary $\mathrm{N}$ excretion occurred which could not be overcome, even by feeding excess amounts of protein and energy.

\section{Hormonal changes after injury}

The endocrine changes following injury have been described in some detail (Moore, 1977; Johnston, 1972) and represent an integrated neuro-endocrine

\section{Table 1. Factors modifying the metabolic response to injury}

Anaesthesia
Haemorrhage
Blood transfusion
Immobilization
Body composition
Protein depleted diet
Dietary protein level
Dietary energy level
Starvation alone
Starvation plus injury
Infection
Burn wound

Anaesthesia

Haemorrhage

Blood transfusion

Immobilization

Protein depleted diet

Dietary protein level

Starvation alone

Starvation plus injury

Infection
Burn wound
Moore (1957).

Flear \& Clark (1 955).

Timoner et al. (1959).

Cuthbertson (1929), Dietrick et al. (1948), Schonheyder et al. (1954).

Moore \& Ball (1952), Cuthbertson (1964), Border (1970).

Munro \& Cuthbertson (1943), Cuthbertson \& Tilstone (1969).

Munro \& Chalmers (1945).

Cuthbertson (1936), Co Tui et al. (1944), Riegel et al. (1947), Werner et al. (1949), Munro (1964).

Lusk (193 I), Keys et al. (1950), Wilkinson (1961), Levenson et al. (1975).

Dudley (1959, 1968), Abbott \& Albertsen (1963), Wilkinson (1966),

Clark (1967).

Wannemacher (1975).

Soroff et al. (1961). 
response to a noxious stimulus, characterized by sympatho-adrenal nervous system discharge, the 'fright' or 'flight' response of Cannon (r923) essential for survival during stress (Selye \& Collip, 1936; Ingle et al. 1947; Campbell et al. 1954). Hume, Stoner and others (Hume \& Egdahl, 1959; Hume et al. 1962; Hume, 1974; Stoner, 1976) have studied the central nervous system activation of the injury endocrine response, but it is the interactions of the post-injury endocrine changes themselves which have attracted most attention (Cuthbertson \& Tilstone, 1969; Hunt, 1972; Moore \& Brennan, 1975). There is an early catecholamine discharge which inhibits the release of insulin and also stimulates glucagon and ACTH production. Increasing corticosteroid levels further inhibit the action of insulin on peripheral tissues. Salt and water metabolism is also disturbed, with rises in aldosterone and $\mathrm{ADH}$ levels. Changes have been noted following severe injury in virtually every endocrine system studied (Schultis \& Beisbarth, 1971). Only recently, however, has the relationship between endocrine and metabolic changes after injury become more fully understood. Moore now considers (Moore \& Brennan, 1975), that most, if not all of the post-injury metabolic changes are due to the control exerted on intermediary metabolism by the endocrine system. This can influence the selection of tissue fuels for oxidation and the rate of oxidation, and can also affect the body's ability to utilize administered nutrients as well as regulate salt and water balance.

This important conceptual advance has been due in large measure to the development of isotopic tracers, more refined biochemical techniques, and basic studies which reveal the dynamic turnover rates of body tissues in normal and starved subjects (Cahill et al. 1966; Keys et al. 1950; Cahill, 1970).

\section{Body cell mass}

The foundations of these advances lay in the studies carried out by Moore and others (Moore, 1946; Moore et al. 1963; Pace \& Rathburn, 1945) on the quantitative assessment of the total mass of body constituents and their individual flux rates. The concept of body cell mass emerged as that fraction of the body in which energy exchange exclusively occurred (Levenson et al. 1975). Levenson in New York recognized specialized subdivisions of body cell mass, and carried out pioneering experimental studies on the rates of protein synthesis and catabolism in the rat after extensive burns (Levenson et al. 1959, 1976). Using ${ }^{15} \mathrm{~N}$-labelled glycine as a tracer, he found that protein synthesis and catabolism were both greatly accelerated in burned animals. This resulted in a net preservation of liver protein, but by contrast, the protein content of the carcase decreased, despite having a much slower turnover rate than liver. This decrease accounted for almost all of the increased urinary $\mathbf{N}$ losses caused by the injury. Reiss found similar liver and muscle protein changes in starved infected rats (Reiss, 1959) but noted a different response in starved control animals, in which there was marked loss of liver or visceral protein with little loss of muscle or peripheral protein stores. Injury and infection were therefore both characterized by net increased liver protein synthesis using amino acids released from net increased catabolism of muscle 
protein stores, changes which could not be attributed to starvation alone (Cahill \& Owen, 1969; Cahill, 1970; Levenson et al. 1975).

\section{Starvation}

The importance of muscle amino acid metabolism and the adaptive changes which occur progressively in late starvation were subsequently studied in detail (Felig et al. 1967, 1969) and the role of alanine, released from muscle, and its importance as a glucose precursor in the liver identified (Felig, 1973), along with more specific information on the factors regulating this process (Exton et al. 1971; Felig and Wahren, 1971; Odessey et al. 1974; Fitzpatrick et al. 1975; Wilmore, 1977). In starvation, liver glucose production from amino acids was found to be progressively reduced, thereby conserving body protein, and favouring long-term survival. After injury, however, it was noted that there was an increased flux of alanine and other amino acids from muscle which were converted by the liver into glucose (gluconeogenesis) (Krebs, I 964). This resulted in increased formation of urea in the liver as a by-product of this process.

\section{Association of $N$ metabolism and energy expenditure after injury}

Kinney in New York, using an indirect calorimetry system (Kinney et al. 1964), studied energy expenditure in relation to metabolic changes in a wide variety of surgical conditions (Kinney et al. 1968; Kinney, Long \& Duke, 1970; Kinney, Duke et al. 1970; Kinney, 1975, 1976). Very small increases in energy expenditure were found after elective surgery. Greater increases occurred in severe postoperative sepsis and in major burns. Before injury, protein breakdown, estimated from urinary nitrogen excretion, contributed only $12-20 \%$ of the total metabolic expenditure, while fat accounted for the remainder. Even after very severe injury, these proportions did not vary. Earlier work on the metabolic effects of infectious fevers had shown, indirectly, similar results (Du Bois, 1924; Peters, I948).

Calorimetric and metabolic studies in the injured rat by Caldwell and his coworkers (Caldwell, 1961, 1962, 1970; Caldwell et al. 1959, 1966; Miksche \& Caldwell, 1967) reaffirmed the observation made in injured patients, that protein catabolism by itself could not provide the increased energy required after burning or severe injury. The evidence did not suggest a specific protein catabolic effect in severe injury (Cairnie et al. 1957). Rather it appeared that there was an increase in metabolism generally via the normal intermediary metabolic pathways.

Kinney presented evidence (Kinney, Long \& Duke, 1970; Kinney, Duke et al. 1970) that protein degradation occurred after injury to provide carbohydrate intermediates via hepatic gluconeogenesis, rather than to meet whole-body energy requirements. He noted that most amino acids yield carbohydrate intermediates or are glucogenic on deamination. While fatty acids can provide two carbon fragments readily for general tissue energy requirements, they cannot be used to provide a net gain of carbohydrate intermediates, glycogen, or circulating glucose (Coleman, 1969). Therefore, while fat stores could be used to meet energy needs in the state of semi-starvation often associated with injury, protein represented the 
only sizeable reserve of carbohydrate intermediates and glucose precursors also essential for survival. These provided a source of carbon skeletons for the synthesis of non-essential amino acids to sustain the synthesis of body protein (Myers, 195०; Krebs, 1964), materials such as alpha oxoglutamate for the Kreb's cycle, new glycerol for the synthesis of triglycerides, and glucose, an essential fuel for organs such as brain, in the absence of adequate oral intake.

\section{Carbohydrate metabolism after injury}

Kinney sought further evidence for his views in the existing literature on changes in carbohydrate metabolism after injury. Previous investigators had ascribed the initial hyperglycaemia following injury to catecholamine mediated rapid mobilization of body carbohydrate stores (Hayes \& Brandt, I952; Drucker et al. 1953; Howard, 1955), together with a decrease in tissue utilization of glucose due to the presence of a 'peripheral resistance' to the actions of insulin (Johnston, 1968; Gump et al. 1974). However, most of these observations were made during the early injury response or 'Ebb Phase' (Cuthbertson, 1942). Carbohydrate stores within the body are insignificant. Therefore, after even short periods of starvation, body glucose requirements must be met by increased hepatic production of glucose from protein precursors. Using an isotope tracer technique to follow dynamic changes in carbohydrate metabolism (Spencer et al. I971), Kinney's group found that in injured and septic patients hyperglycaemia was the result of an increased glucose flow, i.e. an increase in the synthesis of glucose relative to an increased turnover rate. Injury and sepsis apparently did not impair the ability of the body to oxidize glucose (Gump et al. 1974). In severely septic patients, glucose oxidation was increased (Long et al. 197I) and gluconeogenesis could not be suppressed, even by intravenous infusion of glucose (Long et al. 1976). This suggested that after injury, the normal neurohumoral regulation of gluconeogenesis in muscle and liver had ceased to be effective. The explanation for this effect was found to lie in the upset hormonal balance which follows severe injury.

\section{Hormonal control of intermediary metabolism after injury}

Increases in the 'catabolic' hormones, adrenalin, noradrenalin, glucagon and corticosteroids predominate (Allison, 1974). These changes lead to greatly enhanced gluconeogenesis from protein with concomitant depletion of glycogen stores, and accelerated mobilization of fat reserves (Manchester, I968; HimmsHagen, 1967). Wilmore has recently stressed the central role of catecholamines as mediators of the metabolic response to severe thermal injury (Wilmore, Long et al. 1976; Wilmore, 1977), regulating not only heat production, but also tissue substrate flow, while Alberti et al. (1977), have recently highlighted the need to review the role played by cortisol. It may well prove, as Moore \& Brennan (1975) have stated 'that most, if not all, of the post-traumatic metabolism is due to an interplay of endocrine forces on the selection of body fuels for oxidation, and the 
rate of their oxidation, on the ability to utilize extraneous nutrients, and on the conservation of water and salt'.

Clowes et al. (1976) stress the importance of local tissue factors. They demonstrated in patients and experimental animals, that in trauma or high-flow septic states there was decreased glucose uptake by skeletal muscle despite the presence of hyperglycaemia and hyperinsulinaemia. This 'insulin resistant' state appeared to affect solely muscle, as the suppression of lipolysis and reduced levels of free fatty acids also seen in these subjects indicated that adipose tissue had responded normally to the presence of raised insulin levels (Ryan et al. I974). Clowes suggested that muscle 'insulin resistance' led to a sequence of events culminating in a localized energy or tissue fuel deficit in muscle. Because of the altered hormonal climate, even the small amounts of glucose which were metabolized in muscle were not fully oxidized. Most of the glucose was anaerobically degraded to lactate even in the presence of an adequate tissue blood flow and normal oxygen consumption (Clowes et al. 1974). Because of the reduction in FFA and KB availability, fat could not be utilized effectively as an energy source by 'insulin resistant' muscle. This lack of locally available energy in muscle was compensated for by direct oxidation within muscle of the branched-chain amino acids leucine, isoleucine and valine, derived from its own protein structure. Subsequent transamination of these oxidized amino acids to pyruvate produced increased levels of alanine in the blood which, along with the excess lactate, glycerol and certain other amino acids, were cleared from the blood by increased gluconeogenesis in the liver (Odessey et al. 1974), via the alanine and Corie cycles. The increased glucose turnover after injury or sepsis might therefore simply be a by-product of a local energy deficit in skeletal muscle, without the need to postulate an increased energy demand by all the tissues as a cause of wasteful protein degradation. Wilmore (1977) suggests that this view is an oversimplification. It has recently been shown that anaerobic metabolism in the wound itself also contributes lactate to the bloodstream in addition to the lactate and amino acid breakdown products which arise from skeletal muscle. Studies in noninfected injured patients demonstrated that the major glucose outflow from the liver goes to the area of the wound. Wilmore has shown that both heat production and glucose flow increase with the extent of injury and that these two factors appear to change together with time following injury. However, this relationship did not occur because glucose was oxidized as a primary fuel source. Respiratory quotient measurements on the patients studied reflected oxidation of fat as the primary fuel substrate. The reason for increased glucose flow after injury therefore remains undetermined at present.

In the absence of an adequate oral intake selective oxidation of branched-chain amino acids in muscle, irrespective of cause, would result in a failure of new protein synthesis. In particular, preservation of host resistance by an adequate production of specific immunoproteins in injury or in infection (Beisel, 1975; Wannemacher, 1975) might well determine ultimate survival in the nutritionally depleted septic post-operative patient. 


\section{Current nutritional therapy in the critically ill}

Though doubts exist regarding detailed mechanisms of muscle proteolysis and increased glucose flow in severe injury or infection, there is no controversy regarding the effectiveness of current nutritional therapy in improving survival after extensive trauma. Moore in Boston has reviewed this topic at length (Moore \& Brennan, 1975), and considered two main principles of nutritional management after injury to be important. First, the abatement of those injury components which induce or prolong a 'catabolic' neuro-endocrine response in the body. Second, the provision of adequate amounts of appropriate nutrition, in a readily assimilable form, at the correct times after injury, in order to best maintain or restore body composition.

Taking the first of these themes, since it appears that many of the varying afferent inputs of injury such as psychic stimulation, pain, blood loss, hypoxaemia, tissue necrosis and sepsis, have as a common pathway an increased discharge of sympatho-adrenal hormones, much of the standard treatment of the injured patient such as adequate analgesia, replacement of blood and fluid losses, splinting of injured limbs, thorough debridement of wounds, oxygen therapy, and the use of antibiotics, already goes a long way towards meeting Moore's first principle of nutritional management.

In addition to these direct methods of reducing sympatho-adrenal discharge, recent evidence suggests that additional homoeostatic mechanisms may be deliberately invoked in order to further reduce the catecholamine breakdown of body protein. Traditionally the hypercatabolism of thermal injury has been attributed mainly to accelerated water and heat losses from the wound surface which impose a powerful cooling load upon the thermal regulating mechanisms of the body. This leads to a compensatory catecholamine mediated increase in heat production, with rapid depletion of body energy stores. The expected protein and weight losses did not occur after severe burns when patients (Davies et al. 1959; Davies \& Liljedahl, 1970) and experimental animals (Caldwell, 1970; Campbell \& Cuthbertson, 1967) were nursed at thermoneutral ambient temperatures $\left(30^{\circ}-32^{\circ}\right)$ (Tilstone, 1974). The mechanism of this effect is not fully understood (Wilmore, Long et al. 1976; Wilmore, Taylor et al. 1976; Wilmore, 1977). Although some of the reduction in weight loss seen at the higher ambient temperature could be related to reduced sensible heat losses (Caldwell, 1970), it is interesting that Liljedahl (1972) found a marked reduction in the expected excretion of catecholamines after thermal injury when patients were treated in thermoneutral environments compared with ordinary ward temperatures. As interpreted by Clowes et al. (1976) earlier, this would be likely to reduce or unblock the insulin resistant state of skeletal muscle thereby decreasing the need for self-destructive oxidation of muscle branched-chain amino acid pools. More experimental work is required to determine whether this hypothesis is valid or whether it can be effectively applied to injuries other than burns, but the prospect of environmental control of body hormonal climate after injury is appealing. 
It may also be possible partially to overcome muscle insulin resistance by giving excess amounts of the anabolic hormone insulin. Insulin has a specific effect limiting proteolysis after injury independent of the source or amount of energy provided (Woolfson et al. 1977). Insulin therapy can also be effective after injury in enhancing active ion transport across cell membranes, bringing about a beneficial naturesis and diuresis (Flear et al. 1977). This produces a temporary improvement in patients which is similar to that seen during recovery, or a return to anabolism (Moore \& Brennan, 1975).

It is likely that adjunctive hormonal therapy of this type used in carefully selected circumstances, will form an increasing part of the nutritional care of the critically ill. With regard to the provision of adequate nutrition, Blackburn \& Bistrian (1976) have stated that recent developments in enteral and parenteral feedings rank in importance with the discovery of antibiotics in influencing the survival of many patients who would otherwise die. The provision of protein and energy without regard to other factors influencing the rate of depletion of body stores is no longer sufficient. The objective must be to achieve a functional redistribution of protein in order to enhance those aspects of the metabolic response to injury which are beneficial, i.e. protein synthesis, essential for repair, without at the same time irreversibly and perhaps fatally depleting the body mass.

\section{REFERENCES}

Abbott, W. E. \& Albertson, K. (1963). Ann. N.Y. Acad. Sci. 110, 941.

Alberti, K. G., Batstone, G. F. \& Johnston, D. G. (1977). In Nutritional Aspects of Care in the Critically Ill, p. 225. [J. R. Richards and J. M. Kinney, editors]. Edinburgh, London \& New York: Churchill Livingstone.

Allison, S. P. (1974). In Parenteral Nutrition in Acute Metabolic Illness, p. 167. [H. A. Lee, editor]. London \& New York: Academic Press.

Beisel, W. R. (1975). Ann. Rev. Med. 26, 9.

Blackburn, G. L. \& Bistrian, B. R. (1976). Surg. Clin. N. Am. 56, I 195.

Border, J. R. (1970). In Surgery Annual, p. Ir. [P. Cooper and L. M. Nyhus, editors]. New York: Appleton.

Cahill, G. F. (1970). Nero Engl. Y. Med. 282, 668.

Cahill, G. F., Herrera, M. G., Morgan, A. P., Soeldner, J. S., Steinke, J., Levy, P. L., Reichard, G. A. \& Kipnis, D. M. (1966). F. clin. Invest. 45, 175 I.

Cahill, G. F. \& Owen, O. E. (1969). F. clin. Invest. 48, $5^{84}$.

Cairnie, A. B., Campbell, R. M., Pullar, J. D. \& Cuthbertson, D. P. (1957). Br. F. exp. Path. 38, 504 .

Caldwell, F. T. (1961). Surgery 49, 454.

Caldwell, F. T. (1962). Ann. Surg. 155, 119.

Caldwell, F. T. (1970). In Energy Metabolism in Trauma, p. 23. [R. Porter and J. Knight, editors]. London \& Edinburgh: Churchill Livingstone.

Caldwell, F. T., Hammel, H. T. \& Dolan, F. (1966). F. Appl. Physiol. 21, 1665.

Caldwell, F. T., Osterholm, J. L., Sower, N. D. \& Moyer, C. A. (1959). Ann. Surg. 150, 976.

Campbell, R. M. \& Cuthbertson, D. P. (1967). Q. Fl exp. Physiol. 54, I14.

Campbell, R M., Sharp, G., Bryne, A. W. \& Cuthbertson, D. P. (1954). Br. F. exp. Path. 35, 566.

Cannon, W. B. (1923). In Traumatic Shock, New York: Appleton.

Clark, R. G. (1967). Br. F. Surg. 54, 445 . 
Clowes, G. H. A., O’Donnell, T. F., Blackburn, G. L. \& Maki, T. N. (I976). Surg. Clin. N. Am. 56,1169 .

Clowes, G. H. A., O'Donnell, T. F., Ryan, N. T. \& Blackburn, G. L. (1974). Ann. Surg. 179, 684.

Coleman, J. E. (1969). In Duncan's Diseases of Metabolism, p. 89. [P. K. Bondy and L. E. Rosenberg, editors]. Philadelphia \& London: Saunders.

Co Tui, F. W., Wright, A. M., Mulholland, J. H., Carabba, V., Barcham, I. \& Vinci, V. J. (1944). Ann. Surg. 120, 99.

Cuthbertson, D. P. (1929). Biochem. F. 23, 1328.

Cuthbertson, D. P. (1930). Biochem. F. 24, 1244.

Cuthbertson, D. P. (1931). Biochem. F. 25, 236.

Cuthbertson, D. P. (1932). Q. Yl Med. 25, 233.

Cuthbertson, D. P. (1934). Glasgow Med. F. 3, 41.

Cuthbertson, D. P. (1936). Br. J. Surg. 23, 505.

Cuthbertson, D. P. (1942). Lancet i, 433 .

Cuthbertson, D. P. (1964). In Mammalian Protein Metabolism, p. 373. [H. N. Munro and J. B. Allison, editors]. New York: Academic Press.

Cuthbertson, D. P. (1970). In Energy Metabolism in Trauma, p. 98. [R. Porter and J. Knight, editors]. London: Churchill.

Cuthbertson, D. P. (1972). In Parenteral Nutrition, p. 4. [A. W. Wilkinson, editor]. Edinburgh \& London: Churchill Livingstone.

Cuthbertson, D. P., McGirr, J. L. \& Robertson, J. S. M. (1939). Q. Fl exp. Physiol. 29, 13.

Cuthbertson, D. P. \& Tilstone, W. J. (1969). Adv. clin. Chem. 12, 1.

Davies, J. W. L. \& Liljedahl, S. O. (1970). In Energy Metabolism in Trauma, p. 59. [R. Porter and J. Knight, editors]. London: Churchill.

Davies, J. W. L., Ricketts, C. R. \& Bull, J. P. (1959). Lancet i, 346.

Dietrick, J. E., Wheden, G. D. \& Shorr, E. (1948). Am. J. Med. 4, 3.

Drucker, W. R., Miller, M., Craig, J. W., Jeffries, W., Levey, S. \& Abbott, W. E. (1953). Surg. Forum 3, 548.

Du Bois, E. F. (1924). In Basal Metabolism in Health \& Disease. Philadelphia \& New Yort: Lea \& Febiger.

Dudley, H. A. F. (1959). Y. Roy. Coll. Surg. Ed. 4, 137.

Dudley, H. A. F. (1968). F. Roy. Coll. Surg. Ed. 13, r.

Duval, P. \& Grigaut, A. (1918). C. r. Soc. Biol., Paris. 87, 873.

Exton, J. H., Ui, M., Lewis, S. B. \& Park, C. R. (1971). In Regulation of Gluconeogenesis. [H. D. Soling and B. Williams, editors]. New York: Academic Press.

Felig, P. (1973). Metabolism 22, 179.

Felig, P., Marliss, E., Owen, O. E. \& Cahill, G. F. (1969). Adv. Enxyme Regulation 7, 41.

Felig, P., Owen, O. E., Wahren, J. \& Cahill, G. F. (1967). f. clin. Invest. 48, 504.

Felig, P. \& Wahren, J. (1971). F. clin. Invest. 50, 1702.

Fitzpatrick, G. F., Meguid, M. M., O'Connel, R. C., O'Connor, N. E., Ball, M. R. \& Brennan, M. F. (1975). Surgery, St Louis 78, 105.

Flear, C. T. G., Bhattacharya, S. S. \& Nandra, G. S. (1977). In Nutritional Aspects of Care in the Critically Ill, p. 195. [J. R. Richards and J. M. Kinney, editors]. Edinburgh, London \& New York: Churchill Livingstone.

Flear, C. T. G. \& Clark, R. G. (1955). Clin. Sci. 14, 575.

Frawley, J. P., Artz, C. P. \& Howard, J. M. (1955). Archs Surg. 7r, 612.

Grossman, C. M., Sappington, T. S., Burrows, B. A., Lavietes, P. H. \& Peters, J. P. (1945). J. clin. Invest. 24, 523.

Gump, F. E., Long, C. L., Killian, P. \& Kinney, J. M. (1974). f. Trauma 14, 378.

Haskins, H. D. (1907). J. biol. Chem. 3, 321.

Hawk, P. B. \& Gies, W. J. (1904). Am. F. Physiol. 2, 171.

Hayes, M. A. \& Brandt, R. L. (1952). Surgery, St Louis 32, 819.

Himms-Hagen, J. (1967). Pharmac. Reo. 19, 367.

Howard, J. E., Parson, W., Stein, K., Eisenberg, H. \& Reidt, V. (1944). Bull. Yohn Hopkins Hosp. 75, 156.

Howard, J. E., Bigham, R. S. \& Mason, R. E. (1946). Trans. Ass. Am. Phys. 59, 242.

Howard, J. M. (1955). Ann. Surg. 141, 321. 
Hume, D. M. (1974). In Principles of Surgery, p. 1. [S. Schwartz, editor]. New York: McGraw-Hill.

Hume, D. M., Bell, C. C. \& Bartler, F. (1962). Surgery, St Louis 52, I74.

Hume, D. M. \& Egdahl, R. H. (1959). Ann. Surg. 150, 697.

Hunt, A. C. (1972). In The Endocrine Response to Trauma, p. 83. [A. C. Hunt, editor]. Report of a Working Party of the Royal College of Pathologists, London.

Ingle, D. J., Ward, E. O. \& Kuizenga, M. H. (1947). Am. J. Physiol. 149, 510.

Johnston, I. D. A. (1972). Adv. clin. Chem. 15, 225.

Johnston, I. D. A. (1968). Sci., Basis, Med. Ann. Rev. p. 224.

Keys, A., Brozek, J., Henschel, A., Mickelson, O. \& Taylor, H. L. (1950). In The Biology of Human Starvation, p. 329. Minneapolis: University of Minnesota Press.

Kinney, J. M. (1975). In Manual of Surgical Nutrition, p. 223. [W. F. Ballinger, J. A. Collins, W. R. Drucker, S. J. Dudrick and R. Zeppa, editors]. Philadelphia \& London: Saunders.

Kinney, J. M. (1976). In Metabolism and the Response to Injury, p. 121. [A. W. Wilkinson and D. P. Cuthbertson, editors]. Bath: Pitman.

Kinney, J. M., Duke, J. H., Long, C. L. \& Gump, F. E. (1970). F. clin. Path. 23, (Suppl. 4), 65.

Kinney, J. M., Long, C. L. \& Duke, J. H. (1970). In Energy Metabolism in Trauma, p. 103. [R. Porter and J. Knight, editors]. London: Churchill.

Kinney, J. M., Long, C. L., Gump, F. E. \& Duke, J. H. (1968). Ann. Surg. 168, 459.

Kinney, J. M., Morgan, A. P., Domingues, F. J. \& Gildner, K. J. (1964). Metabolism 13, 205.

Krebs, H. (1964). Proc. R. Soc. Lond. B. 159, 545.

Kreiger, H., Abbott, W. E., Levey, S., Babb, L. L. \& Holden, W. D. (1954). Surgery, St Louis 36,580 .

Levenson, S. M., Crowley, L. V., Oates, J. F. \& Glinos, A. D. (1959). Proc. Second Army Sc. Conf. 2, 109.

Levenson, S. M., Crowley, L. V. \& Seifter, E. (1975). In Manual of Surgical Nutrition, p. 236. [W. F. Ballinger, J. A. Collins, W. R. Drucker, S. J. Dudrick and R. Zeppa, editors]. Philadelphia \& London: Saunders.

Levenson, S. M., Crowley, L. V. \& Seifter, E. (1976). In Metabolism and the Response to Injury, p. 26r. [A. W. Wilkinson and D. P. Cuthbertson, editors]. Bath: Pitman.

Liljedahl, S. O. (1972). In Parenteral Nutrition, p. 208. [A. W. Wilkinson, editor]. Edinburgh \& London: Churchill Livingstone.

Long, C. L., Kinney, J. M. \& Geiger, J. W. (1976). Metabolism 25, 193.

Long, C. L., Spencer, J. L., Kinney, J. M. \& Geiger, J. W. (I97I). F. Appl. Physiol. 31, 102.

Lusk, G. (1931). In The Science of Nutrition, Philadelphia \& London: Saunders.

Manchester, K. L. (I 688 ). In Biological Basis of Medicine, p. 22 r. [E. E. Bittar and N. Bittar, editors]. London \& New York: Academic Press.

Mestrezat, W. (1918). C. r. Soc. Biol. Paris 81, 888.

Miksche, L. W. \& Caldwell, F. T. (1967). Surgery, St Louis 62, 66.

Ministry of Health (1964). Rep. Publ. Hlth Med. Subj. London, No. III London: HM Stationery Office.

Moore, F. D. (1946). Science, N.Y. 104, 157.

Moore, F. D. (1957). Rec. Prog. Horm. Res. 13, 511 .

Moore, F. D. (1977). In Davis-Christopher Textbook of Surgery: The Biological Basis of Modern Surgical Practice, p. 27. [D. C. Sabistan, editor]. Philadelphia \& London: Saunders.

Moore, F. D. \& Ball, M. R. (1952). In The Metabolic Response to Injury. Springfield Illinois: Chas. C. Thomas.

Moore, F. D. \& Brennan, M. F. (1975). In Manual of Surgical Nutrition, p. 169. [W. F. Ballinger, J. A. Collins, W. R. Drucker, S. J. Dudrick and R. Zappa, editors]. Philadelphia \& London: Saunders.

Moore, F. D., Olesen, K. H., McMurray, J. D., Parker, H. V., Ball, M. R. \& Boyden, C. M. (1963). In The Body Cell Mass and its Supporting Environment. Philadelphia \& London: Saunders.

Munro, H. N. (1964). In Mammalian Protein Metabolism, p. $3^{81}$. [H. N. Munro and J. B. Allison, editors]. New York: Academic Press.

Munro, H. N. \& Chalmers, M. I. (1945). Brit. f. exp. Path. 26, 396.

Munro, H. N. \& Cuthbertson, D. P. (1943). Biochem. F. 37, 12. 
Myers, J. D. (1950). F. clin. Invest. 29, 1421.

Odessey, R., Khairallah, E. A. \& Goldberg, A. L. (1974). 7. biol. Chem. 249, 7623.

Pace, N. \& Rathburn, E. N. (1945). F. biol. Chem. 158, 685 .

Peters, J. P. (1948). Am. J. Med. 5, 100.

Reiss, E. (I959). Metabolism 8, I5I.

Riegel, C., Koop, C. E., Drew, J., Stevens, L. W. \& Rhoads, J. E. (1947). F. clin. Invest. $26,18$.

Ryan, N. T., Blackburn, G. L. \& Clowes, G. H. A. (1974). Metabolism 23, 108 r.

Schonheyder, F., Heilokov., N. S. C. \& Oleson, K. (r954). Scand. F. clin. Lab. Invest. 6, 178.

Schultis, K. \& Beisbarth, H. (1971). In Parenteral Nutrition, p. 31. [F. W. Ahnefeld, C. Burri, W. Dick and S. M. Halmaggi, editors]. Berlin: Springer-Verlag.

Selye, H. \& Collip, I. P. (1936). Endocrinology 21, I69.

Shaffer, P. A. (1908). FAMA, LI, I 2.

Shaffer, P. A. \& Coleman, W. (1909). Archs Int. Med. 4, $53^{8}$.

Soroff, H. S., Pearson, E., Arney, G. K. \& Artz, C. P. (1961). Surg. Gyn. Obstet. 112, 425.

Spencer, J. L., Long, C. L. \& Kinney, J. M. (1971). Indust. Eng. Chem. Fund. 10, I.

Stoner, H. B. (1976). In Metabolism and the Response to Injury, p. 179. [A. W. Wilkinson and D. P. Cuthbertson, editors]. Bath: Pitman.

Thompson, V. (1974). Acta Med. Scand. 91, 1.

Tilstone, W. J. (1974). In Parenteral Nutrition in Acute Metabolic Illness, p. 197. [H. A. Lee, editor]. London \& New York: Academic Press.

Timoner, J., Riddell, A. G. \& Carr, G. R. (1959). Clin. Sci. 18, 561.

Wannemacher, R. W. (1975). In Total Parenteral Nutrition: Premises and Promises, p. 85 . [H. Ghadimi, editor]. New York: Wiley.

Werner, S. C., Habit, D. U., Randall, H. T. \& Lockwood, J. S. (1949). Ann. Surg. 130, 688.

Wertheimer, Fabre \& Clogne (1919). Bull. Mém. Soc. Chirgns Paris 45, 9.

Wilkinson, A. W. (1961). Lancet ii, 783.

Wilkinson, A. W. (1966). In Wound Healing, p. 153. [C. Illingworth, editor]. London: Churchill.

Wilmore, D. W. (1977). In The Metabolic Management of the Critically Ill. New York \& London: Plenum.

Wilmore, D. W., Curreri, P. W., Spitzer, K. W., Spitzer, M. E. \& Pruitt, B. A. (1971). Surg. Gyn. Obstet. 132, 881.

Wilmore, D. W., Long, J. M., Mason, A. D. \& Pruitt, B. A. (1976). In Metabolism and the Response to Injury, p. 287. [A. W. Wilkinson and D. P. Cuthbertson, editors]. Bath: Pitman.

Wilmore, D. W., Taylor, J. W., Hander, E. W., Mason, A. D. \& Pruitt, B. A. (1976). In Metabolism and the Response to Injury, p. 274- [A. W. Wilkinson and D. P. Cuthbertson, editors]. Bath: Pitman.

Woolfson, A. M. J., Heatley, R. V. \& Allison, S. P. (1977). In Nutritional Aspects of Care in the Critically Ill, p. 367. [J. R. Richards and J. M. Kinney, editors]. Edinburgh, London \& New York: Churchill Livingstone. 